\title{
CULTURAL CAPITAL AND IRANIAN WOMEN'S SUBMISSIVENESS: PIERRE BOURDIEU'S THEORY OF PRACTICE
}

Marzieh Kouchaki, Islamic Azad University, Kerman, Iran, kouchakimarzieh@gmail.com

Hassan Shahabi, Islamic Azad University, Kerman, Iran, hshahabi@iauk.ac.ir

Shahram R. Sistani, Bahonar University of Kerman, Kerman, Iran, shahram.sistani@uk.ac.ir

DOI: 10.31902/fll.35.2021.1

\begin{abstract}
Men's domination and women's submissiveness are the principles of patriarchal societies. In Iran's patriarchal society, Iranian women also submit to men's power in various fields. This article examines Fariba Vafi's My Bird and Zoya Pirzad's Things We Left Unsaid to scrutinize the interrelations between different forms of cultural capital and Iranian women's subordination in the fields of vocation and marriage. Drawing on Bourdieu's theory of practice, the findings of this paper show that Iranian men cause Iranian women to be obedient in the fields of vocation and marriage with the help of institutionalization and habituation of various forms of cultural capital in Iranian women. This article also demonstrates that Iranian women have to eventually submit to the patriarchal culture of Iran despite their access to self-awareness and effort to resist.
\end{abstract}

Keywords: Pierre Bourdieu, cultural capital, filed, habitus, symbolic violence, vocation, marriage, My Bird, and Things We Left Unsaid.

\section{Introduction}

To investigate Iranian women's submissiveness in the fields of vocation and marriage, it seems necessary to uncover the objective structures of Iran's social world that define the constraints on interactions. Bourdieu defines social formations as "systems of relations of power and relations of meaning between groups and classes" (Bourdieu and Wacquant 7). The subjective and internalized experience of individuals should also be taken into account to find out the constructions that determine the 
actions of agents. Bourdieu states that "there exists a correspondence between social structures and mental structures, between the objective divisions of the social world- particularly into dominant and dominated in the various fields- and the principles of vision and division that agents apply to it" (Bourdieu and Wacquant 12).

Culture provides mechanisms in the social structures that bring about the reproduction of masculine domination and Iranian women's submissiveness in the fields of vocation and marriage. Bourdieu believes that culture is regarded "as a form of capital with specific laws of accumulation, exchange, and exercise of power" (Swartz 8). In fact, culture is an "embodied form of the relation of domination" which causes "that relation to appear as natural" (Bourdieu, Masculine 35). Therefore, women perceive "all reality, and in particular, the power relations in which they are held, through schemes of thought that are the product of embodiment of those power relations" (Bourdieu, Masculine 33-34). The purpose of this study is to show how cultural capital can lead to Iranian women's subordination to men's domination in the fields of vocation and marriage through Pierre Bourdieu's theory of practice as well as the detailed analysis of the selected novels.

\section{Theoretical Framework and Methodology}

Pierre Bourdieu is an important theorist in the field of cultural studies whose theory of practice considers an individual's practices as "more than actions of an individual" and emphasizes that practices encompass "social and cultural relations, systems, and structures" (Beckman et al. 3). His theory is composed of four concepts that clarify the formation of individuals' practices, the exertion of masculine domination, and women's submissiveness.

The first concept is capital. For Bourdieu, capital includes "untouchable but culturally significant attributes, referred to as symbolic capital, along with cultural capital, defined as culturally-valued taste and consumption patterns" (Webb et al. 22). Thus, culture is introduced as a form of capital whose important characteristic is its embodiment in "the form of long-lasting dispositions of the mind and body" (Bourdieu, "The Forms" 17). This means that "the principle of a field is incorporated within the corporality of the person as principles of consciousness in predispositions and propensities" (Grenfell, Key 105).

The second concept is field. Fields are "networks of social relations, structured systems of social positions" (Everett 60). Each field has "its own distinctive logic of practice" (Grenfell, Key 70) that Bourdieu refers to as doxa: "pre-reflexive, shared but unquestioned opinions and perceptions mediated by autonomous social microcosms (fields) which 
determine 'natural' practice and attitudes via the internalized 'sense of limits' and habitus of the social agents in the fields" (Grenfell, Key 120). Therefore, doxa in each field contributes to the formation of individuals' habitus.

Habitus, the third concept, predisposes social agents to certain ways of behaving. "The habitus, as a system of dispositions to a certain practice, is an objective basis for regular modes of behavior, and thus for the regularity of modes of practice, and if practices can be predicted [...] this is because the effect of the habitus is that agents who are equipped with it will behave in a certain way in certain circumstances" (Reay 433). Therefore, practices are the result of what Bourdieu calls "an obscure double relationship" (Bourdieu and Wacquant 126) or "an unconscious relationship" (Bourdieu, Sociology 76) between habitus and field. These concepts all point to the fourth concept called symbolic violence.

Symbolic violence is defined as "the violence which is exercised upon a social agent with his or her complicity" (Bourdieu and Wacquant 167). In other words, "agents are subjected to forms of violence, but they do not perceive it that way; rather, their situation seems to them to be the natural order of things" (Webb et al. 25). This is because of misrecognition: "the agent engaged in practice knows the world [...] without objectifying distance, takes it for granted, precisely because he is caught up in it, bound up with it; he inhabits it [...] in the form of the habitus" (Bourdieu, Pascalian 142-43). Therefore, masculine domination and Iranian women's submissiveness are the outcomes of women's misrecognition of the symbolic violence that is considered as something natural by them.

\section{Cultural Capital and Iranian Women's Submissiveness in the Field of Vocation in My Bird}

Fariba Vafi is an Iranian contemporary female novelist who narrates women's status in the field of vocation. The trace of culture in the creation of a gender-based division of labor in the vocation field is perceptible in her novel My Bird. Vafi reflects the reaction of her female character in relation to this gender-based division of labor and portrays the damaging impacts it can have on her, as well.

The gender-based division of labor in the vocation field in $M y$ Bird can be understood and explained considering the relationship between people's practices and the contexts in which those practices occur. Bourdieu refers to these contexts, which produce and transform attitudes and practices, as cultural fields. Bourdieu defines the cultural field as "a series of institutions, rules, rituals, conventions, categories, 
designations, appointments, and titles which constitute an objective hierarchy, and which produce and authorize certain discourses and activities" (Webb et al. 21-22).

It should be taken into consideration that a person's amount of power within a field depends on his/her position within the field and the amount of capital he or she has. In fact, "the extent to which agents are endowed with [different] forms [of capital] will determine the extent of their power" (Stewart 65). Of course, the distribution of the different types of capital at any given moment "represents the immanent structure of the social world" (Bourdieu, "The Forms" 15). Iran's social structures are such that they provide men with access to various forms of capital, such as economic capital. Therefore, Iranian men occupy a higher position in the social hierarchy of the patriarchal society of Iran and are considered as powerful agents. Iranian men use their position and power to "dominate the field" of vocation and "have the means to make it function to their advantage" (Bourdieu, Cultural Production 88). In other words, men take advantage of their power to "designate what is 'authentic' capital" (Webb et al. 23) in the vocation field.

Amir, the female protagonist's husband, considers women as "housekeepers and servants in order to serve their families, not as beings with ability and power who can play an active role in society as men" (Sayyadi Nejad and Mortezae 71). In other words, Amir believes that staying at home and doing domestic duties are forms of authentic capital for women in the field of vocation. The female protagonist, who thinks that "I don't enjoy the cool air of the air conditioning because Amir has to work in the hot sun [...] It is not fair to have his face burn under the sun while my face is gleaming because of eating and sleeping well. It is not fair [...] Amir brings in money and we spend it" (Vafi 40), decides to look for a job for herself to help Amir to improve the family's economic status. But when the female protagonist tells Amir about her decision and asks permission from him to do so, she faces her husband's humiliation and disagreement. The female protagonist says, "I will get a job. I have worked before. I can do it." (Vafi 40). Amir responds, "If you want to be useful, it is better to raise your kids well" (Vafi 40).

Another authentic cultural capital, valued and emphasized by the social structures of the patriarchal society of Iran, is the capital of motherhood. This capital is closely connected to the aforementioned forms of capital in the previous paragraph. Actually, this form of capital helps Iranian men to preserve the gender-based division of labor and, therefore, keep women subordinated to themselves. "Being a biological feminine and motherhood have made women dependent upon men and have condemned them to be at the service of their children, passive, 
and powerless" (Shahbazi et al. 300). This form of capital is primarily habituated in women and may not be consciously noticed. Therefore, "the acquisition of gender identity does not pass through consciousness, it is not memorized but enacted at a pre-reflexive level" (McNay 101). The bodily dispositions are thus embodied as a form of practical mimesis: "the body believes in what it plays at, it weeps if it mimes grief" (Bourdieu, Logic 73). In fact, this embodiment is the outcome of "the composition and volumes of capital that can be accrued and carried by the body and the fit between the habitus and the field" (Skeggs 22). Through this embodiment, habitus "engages the fundamental principles of the social world, expressed through the division of labor, the division of work, and the division of domination" (Winkle-Wanker 10). Based upon the prevalence of the cultural capital of motherhood in the patriarchal society of Iran and its embodiment in Iranian women's minds, the female protagonist of the novel My Bird embraces a new gender identity that is the acceptance of the role of motherhood. "As soon as you get married [...] everybody's counting the seconds to hear the big news [...] You go to the hospital, and the next day they put a small and unfamiliar being in your arms that reminds you of a wet sparrow [...] From that moment on, you become a mother" (Vafi 66-67). Since the cultural capital of motherhood is valued as an advantage for women in the patriarchal community of Iran, the female protagonist's individual identity is faded in her new identity of being a mother. In fact, the society recognizes her new identity more than her individual identity. "Before you know it, wherever you go they ask about your kids, and you have to drag them with you everywhere. Your life is connected to two other human beings in every possible way" (Vafi 68).

The cultural capital of motherhood is closely related to the individuals' social capital. Bourdieu defines social capital as "social connections, honorability, and respectability" (Distinction 122). In other words, cultural capital can "interact and work together with social capital to perpetuate privilege in that one's social capital, one's social connections, drives the availability of cultural capital that one acquires and the cultural capital that is recognized in [the] particular field" of vocation (Winkle-Wanger 13). The female protagonist's social connections with other women reinforce the cultural capital of motherhood as a part of a woman's identity. Women hear the sound of a woman, "as old as the world," who whispers in their ears that "now that your work is changing diapers, and you actually have shown great aptitude in that, why not use this God-given talent to raise other kids, and a thousand other reasons. Then you get pregnant with your second child and become a complete mother" (Vafi 67). 
Although these embodied forms of cultural capital seem to be natural and are turned into Iranian women's habitus, they can thus become forms of symbolic capital, which is "characterized by recognition and prestige- and is misrecognized as an innate attribute" (Stewart 69). These symbolic forms of capital can reveal the symbolic violence exerted on Iranian women. The symbolic violence actually stems from "the realization of a world view or social order anchored in the habitus of the dominating as well as the dominated. This symbolic violence requires that subjective structures- the habitus- and objective conditions be in harmony and that 'what is proper' be incorporated" (Krais and William 58). The female protagonist is "caught in her passive feminine pole" (Shahbazi et al. 300) due to the existing symbolic violence in the patriarchal society of Iran, exerted on her through the discussed forms of symbolic capital.

This symbolic violence has two destructive effects on the female protagonist. Influencing the mother-child relationship is the first detrimental impact of symbolic violence. The female protagonist has to "stay in that house all alone with children who know nothing" (Vafi 8687). This makes her frustrated and bored. She is "bored of constantly having to take care of the kids [...] She is tired of the long days turning to night, and of long nights that are filled with tears. The polar bear yells at the kids for no reason" (Vafi 70). The second devastating effect of this symbolic violence is that love is faded between the female protagonist and her husband. Bourdieu believes that family has "a very real purpose and its daily existence depends on the practical and symbolic work that transforms the obligation to love into a loving disposition" (Silva 88). Bourdieu claims that the family "is a fiction, a social artefact, an illusion in the most ordinary sense of the world, but a 'well-founded illusion,' because being produced and reproduced with the guarantee of the state, it receives from the state at every moment the means to exist and persist" (Bourdieu, "The family" 73). But, such a loving disposition and taste cannot be found in the relationship between the female protagonist and her husband. When the female protagonist asks her husband to "tell [her] something good, something about love," her husband answers that "where is love? It's all dirty staff" (Vafi 13). However, the female protagonist believes that "perhaps love is inside us. [She thinks] that with love as a visa you can go anywhere and live there" but "[she does not] really have such a permit in [her] pocket" (Vafi 63).

There are numerous examples in the novel that point to the lack of a loving disposition in their relationship. Amir never pays attention to his wife while talking. She says, "I was not finished yet. I was still talking 
when, half asleep, he covered my mouth with his hand [...] I was shocked; loneliness and dismay filled the space between Amir and me like a second wife" (Vafi 10). Also, when the female protagonist asks Amir to come in from the backyard, whatever she calls him, she gets no answer. "He doesn't see me. He doesn't hear me [...] Where is Amir? [...] Don't know. He is no longer in this house. He is gone" (Vafi 16). Or when the female protagonist finds the tape Amir was looking for and gives it to him, he does not look at her thankfully. Instead, he looks at her "as if it's [her] fault that [she does not] look like a woman he could passionately love at this moment" (Vafi 61). Moreover, when she begs Amir to take the family with him abroad, he says, "don't cling to me like this. Stay here close to you for what" (Vafi 85). Lack of a loving disposition and taste causes Amir to have a scornful look at his wife. This is because of The principle of isotimie- equality in honor-that governs these games of masculine competition excludes the feminine entirely. This exclusion from the realm of masculine privilege accords women a certain critical insight- the 'lucidity of the excluded'- into masculinity. However, their subordinate position means that women remain complicit with these games and thus, participate by proxy in their own subordination and serve as 'flattering mirrors' to the games of men. (McNay 107)

It is possible to point to the scornful look of men towards women from the female protagonist's narration. Amir says, "you've become really fat, like a buffalo. I like the slender and elegant girls walking along the street" (Vafi 100). Also, Amir sometimes tells her that "[her] belly reminds him of a drum, and [her] legs of a camel. Sometimes [she is] transformed into a crocodile, but [she] always end[s] up as a polar bear" (Vafi 52). In Iran's patriarchal society, "despite the fact that Islam honors women and respects their status in society, scornful looks and pessimism towards women can be observed due to the masculine outlooks and the fanatical views" (Sayyadi Nejad and Mortezae 73). This scornful look causes the female protagonist to "lose her confidence so much that she truly considers herself as an animal" (Sayyadi Nejad and Mortezae 72). This can be understood when the female protagonist says, "the polar bear is sleeping under the blanket. The polar bear is telling stories for the kids. She cooks lentils for them, and in the afternoons she takes them out to play" (Vafi 69-70). Or when Shahla, her sister, tells her that "you are no mother!" to show her protest against her yelling at the children for no reason, she screams and says, "no, I am not. I am not a mother. I am a cow, a bear" (Vafi 70).

The female protagonist, who achieves a kind of self-awareness, tries to resist the valued symbolic forms of capital in Iran's patriarchal 
society and the symbolic violence imposed on women. Her selfconsciousness can be understood from her idea about the basement. She says, "I like the basement [...] Sometimes it's the only place that you can go from the ground level. It's been a long time since I realized that I have been carrying a basement with me. Since I have discovered the basement is my starting point, I stop there often" (Vafi 129). In fact, the basement can be the symbol of her suppressed femininity that she has never had the courage to face with. "This time I have found the courage to walk there [...] The basement no longer scares me. I want to go there. This time with my eyes open, feeling no fear [...] I know that I can return to the basement anytime I want, like a traveler who returns to her homeland" (Vafi 129).

Despite the female protagonist's self-awareness, the only reaction that she shows against the imposed forms of symbolic capital and, therefore, the symbolic violence and its damaging effects is silence. Silence is known as a precious capital for women, and women are thus encouraged to be silent. Family "operates as a central site of normalization and naturalization" (Skeggs 21). Silence as an "embodied form of cultural capital is transmitted to the child in the home environment. Children exposed to prestigious cultural capital practices from an early age acquire cultural capital, often unconsciously" (Stewart 69). Women in the families undertake the transmission of forms of cultural capital because women are considered to be responsible for "the cultural reproduction in the family and for the transmission of certain cultural values during early socialization of the next generation" (Lagaert 19). Women do what Lovell calls "the cultural housekeeping" (39). In other words, women are "assigned to the management of the symbolic capital of the family" (Bourdieu, Masculine 99). The female protagonist is raised in a house where this cultural capital of silence has been internalized. Thus, as a young girl, she has to adapt not only herself but also her attitudes to this form of cultural capital. She remembers her childhood that was filled with absolute silence. "I remembered that my silence has a history. I have been praised for it time and again [...] My silence was considered my best asset" (Vafi 19). She also recalls her Aunt Mahboub teaching and demanding her to keep everything in her heart and not be like tattletales. "She pressed her hand on my bony chest: 'A woman should learn to keep everything here'" (Vafi 28). She recalls how she was admired by the women in the family and especially Aunt Mahboub "for being reserved, for being secretive" (Vafi 20). Therefore, the female protagonist, who understands that this valuable cultural capital belongs to women, soon realizes that she "was like a chest full of secrets with a tight lid" (Vafi 20). The cultural capital of silence forms the 
female protagonist's habitus. She uses the institutionalized cultural capital of silence and remains silent in the face of the symbolic violence imposed on her. The female protagonist considers her husband a symbol of the culture of Iran's patriarchal society that imposes symbolic violence on her. She shows her dissatisfaction by portraying her husband's death and even his burial in her mind. "Death would certainly make him dearer [...] I would cry for Amir [...] The woman would hold my shoulders and give me sweet drinks, but I would scream, 'Amir, come back. What am I going to do with these kids, Amir?'" (Vafi 56-57). In fact, she kills her husband deep inside her and performs a mournful show at his death to show how much she is fed up with the existing culture. "I've had enough [...] of everything, of this life [...] Sadness has blown up like a balloon inside me. My eyes are full of tears" (Vafi 50).

Therefore, it can be understood that various forms of cultural capital in the patriarchal society of Iran have established gender discrimination in the field of vocation. Forming Iranian women's habitus, these forms of capital have made them accept this discrimination as the natural order of the field of vocation. Therefore, a kind of symbolic violence occurs. This leads to masculine domination and Iranian women's submissiveness in the vocation field.

\section{Cultural Capital and Iranian Women's Submissiveness in the Field of Marriage in Things We Left Unsaid}

Zoya Pirzad is another contemporary Iranian woman novelist who has focused on the influential role of cultural capital, embedded in Iran's social structures and individuals' unconscious minds, in the Iranian women's marriage field. In her novel Things We Left Unsaid, Pirzad represents how cultural capital can determine and affect women's destiny in the field of marriage through her three female characters of the novel, namely Mrs. Nurollahi, Elmira Simonian, and Alice that will be analyzed respectively.

\subsection{Mrs. Nurollahi's Marriage Field}

Mrs. Nurollahi, one of the female characters in Things We Left Unsaid, can point to the prevalent culture of Iran's patriarchal society in the field of marriage. In the marriage field in Iran's male-dominated society, parallel-cousin marriage is seen as an ideal and accepted cultural principle. Therefore, the marriage contract between the two brothers' sons and daughters is recognized as a form of capital. Bourdieu states that "marriage to the father's brother's daughter [or son] is the most blessed of all marriages, and the most likely to call down blessings on the group" (Outline 44-5). 
In the Milk Bar, Mrs. Nurollahi tells Clarice about how she married her husband. "My own mother and father, who would be considered educated and progressive, tried to move mountains to get me to marry my cousin" (Pirzad 176). Her parents are also under the influence of the male-centered society of Iran's objective structures that produce unconscious dispositions to make parallel-cousin marriage possible and even necessary in the marriage field. In fact, the cultural "rule's trick is to cause it to be forgotten that agents have an interest in obeying the rule, or more precisely, in being in a regular situation" (Bourdieu, Outline 22). Her parents believe that "family marriages are not only frowned on, but they are a kind of good deed [...] The marriage of paternal cousins is made in heaven" (Pirzad 176). Thus, it can be inferred from her parents' marriage beliefs that "parallel-cousin marriage may impose itself as a necessity which is, however, not that of a genealogical rule. In practice, this ideal marriage is often a forced choice, which people sometimes try to pass off as a positive choice of the idea, thus making a virtue of necessity" (Bourdieu, Outline 46).

However, Mrs. Nurollahi is a social activist and defender of women's rights. She sees this parallel-cousin marriage as a form of cultural capital and ideology "according to which [a man] has a sort of 'right of pre-emption' over his parallel cousin" (Bourdieu, Outline 46). She believes that this type of marriage contributes to "the ideology of masculinity which gives the man superiority, and therefore the initiative, in all relations between the sexes and especially in marriage" (Bourdieu, Outline 46). Thus, she tries to resist and not to submit herself to the forced marriage by her parents. She finally marries a boy named Payman, whom she loves, with the help of her cousin. "Well, we all joined forces- he, my cousin, and I- and kept talking it up to all the mothers and fathers concerned until they finally gave in and consented" (Pirzad 177).

By getting married to Payman, Mrs. Nurollahi acts against the marriage field's valued capital, which is parallel-cousin marriage, in Iran. Despite her efforts to avoid the predetermined capital of this field and what is happening to other girls in her situation, her representative resistance to this popular cultural capital of the marriage field does not end in a favorable result. This is evident when Clarice asks her whether she feels satisfied with her marriage. Mrs. Nurollahi starts talking about her clothes model and its English collar instead of answering Clarice's question. "After I wore it a few times, it got to be just another dress. Of course, I still love it. I'm careful not to stain it, and each time I wear it, I shake it out back up in the closet so it won't get wrinkled, but [...]" (Pirzad 177). Her answer reflects her incomplete satisfaction with living 
with Payman. This happens because "there is no way out of the game of culture" (Bourdieu, Distinction 12). Moreover, in Iran's patriarchal society, "one of the principal functions of [the field of] marriage is to reproduce the social relations of which it is the product," and thus, "the different types of marriage [...] should correspond very closely to the characteristics of the social relations which have made them possible and which they tend to reproduce" (Bourdieu, Outline 52). Therefore, when there is no way out of the game, the best option is "to understand the game and work out the most appropriate and useful ways of playing it" (Webb et al. 147). Following her own capital and criterion, Mrs. Nurollahi is not successful and cannot act appropriately in the game of culture. In fact, her dissatisfaction is the outcome of disregarding the common tradition of parallel-cousin marriage in the patriarchal society of Iran and ignoring her parents' advice to marry her cousin.

\subsection{Elmira Simonian's Marriage Field}

Elmira Simonian is Emile's mother. She is from a wealthy family. Her father has provided her with everything, and she feels no deficit. Mrs. Simonian remembers her past as such: "the large garden, the highceiling rooms, the wood floors of the corridors, all the expensive furniture. My father used to say, 'what more could you want?' For years I didn't know what I wanted" (Pirzad 165). Therefore, it can be inferred that Mrs. Simonian's marriage field is strongly tied to other forms of capital in Iran's patriarchal society, including economic capital and social capital. Economic capital is "monetary and material wealth, commodities, and physical resources" (Everett 62) that are "immediately and directly convertible into money" (Bourdieu, "The Forms" 243). But like other forms of capital, economic capital is unequally distributed among social classes and class fractions.

Economic capital is connected to how economic strength can be changed to symbolic capital. Symbolic capital is "any property (any form of capital whether physical, economic, cultural or social) when it is perceived by social agents endowed with categories of perceptions which cause them to know it and to recognize it, to give it value" (Grenfell, "Applying" 24). This economic capital forms Mrs. Simonian's father's habitus. Webb et al. consider the habitus as "a concept that expresses, on the one hand, the way in which individuals 'become themselves'- develop attitudes and dispositions- and, on the other hand, the ways in which those individuals engage in practices" (xii- xiii). Her father's habitus and dispositions about financial status make him believe that "a perfect match means that the two families-in-law should share a similar social status, income, and family background. A relationship, 
especially for a couple, may not be stable or happy if there is a big gap between the husband and wife in terms of [their wealth and social status]" (Huang 47). Therefore, he opposes her daughter's only wish, to marry the boy whom she loved. Mrs. Simonian says, "when I asked for it, he said no" (Pirzad 165). Her father's reason for his disagreement is that her favored man is not a wealthy man. Actually, he believes that "a poet was not the kind of person to build a life with" (Pirzad 165). Her father keeps telling her that "it was because of my money that he wanted to marry [you ...] no one falls in love with a midget girl" (Pirzad 165). However, one can never "be admitted into the upper class through marriage" (Webb et al. 42). Therefore, Mrs. Simonian and her favored man are not allowed to marry each other because of being from different economic and financial backgrounds.

On the other hand, Mrs. Simonian's marriage field depends on social capital, too. Bourdieu conceptualizes social capital as "social connections, honorability and respectability" (Distinction 122) that work as a form of capital in social settings. The concept of social capital is conflated with cultural capital. Franklin states that cultural capital can be defined more communally as "the sense of group consciousness and collective identity that serves as an economic resource for the financial and material support of business enterprises aimed the advancement of an entire group" (177). Thus, in the economic field, agents "compete for economic capital by way of various investment strategies using accumulated economic capital" (Bourdieu, Cultural Production 6). One strategy is to take advantage of social capital because "social networks and membership become a resource to be used to increase one's entry and standing in the game of industrial relations" (Sayce 475). Mrs. Simonian's father intends to benefit from this strategy to keep and increase his position and power in the economic field. He wants her daughter to marry a wealthy man whom he approves of. Mrs. Simonian says, "my husband and my father did fall in love. They fall in love with each other's money" (Pirzad 165). Therefore, it can be inferred that the key feature of social capital is that "it enhances other forms of capital [namely economic capital] and acts as an accelerator" (Grenfell, "Applying" 23). Mrs. Simonian's father can accelerate the enhancement of his economic capital by developing his social network and convincing her daughter to marry a rich man.

Mrs. Simonian has to submit to her father's demand and marries the rich man her father has chosen for her. When her husband dies, she thinks she has been released from a forced marriage, and now, it is time to marry her youthful beloved man. So, she goes to Paris and thinks that she is the luckiest woman on earth. But, she shows a picture of a large 
grave in Paris to Clarice and tells her that her beloved man died very soon. "A few months later he was gone, too [...] I buried him in PèreLachaise" (Pirzad 166). Thus, she cannot achieve her long-held dream and prefers to spend the rest of her life with her son and granddaughter. Actually, she is the victim of the valued forms of capital in her marriage field.

\subsection{Alice's Marriage Field}

In the culture of Iran's patriarchal society, marriage is recognized as a sort of capital. In fact, this cultural capital is related to the "socialization of culturally relevant tastes, preferences, or norms that act as a form of currency in the social realm [... and] are primarily habituated, anyway not to be consciously noticed" (Winker-Wagner 5). Actually, cultural preferences are manifested through the concept of taste. "Tastes are acquired dispositions that are one aspect of habitus" (Winker-Wagner 11). In other words, habitus is "the accumulation of one's tastes as dispositions" (Winker-Wagner 12). Hence, "taste, rooted in the field from which one is acting and the habitus or one's set of dispositions, can act as cultural capital" (Winker-Wagner 12). Marriage as a cultural taste and disposition is habituated in Alice's unconscious mind. Alice is Clarice's sister. She is an educated woman, having a bachelor in England as an Operating Room Charge Nurse. She works in an out-of-home environment and is present in the community. However, her only cultural preference is marriage, and she has no purpose but to marry, like other women in Iran's patriarchal society. This cultural taste forms her habitus and generates her formula of lifestyle. If Alice has studied in England, she has only sought to find an English husband. "Alice would go to England for a few years, ostensibly to study nursing, but secretly hoping to find an English husband" (Pirzad 62).

Family has a great role to transfer forms of cultural capital and form individuals' habitus and dispositions. "Cultural capital is primarily acquired through one's social origin, family [... Family] helps to explain the intergenerational transference of lifestyle" (Winker-Wagner 6). Alice's mother considers marriage a form of capital necessary for a single girl. She wishes that her daughter marry as soon as possible and even makes a vow for her. "I always hoped Alice would get married in our church here in Abadan. God bless the cross in that altar! It has granted each and every favor I prayed for and every vow I made. For the safe delivery of your babies, for the setting of Armen's broken arm; for the quick recovery of the twins when their tonsils were removed. And now for this" (Pirzad 240). In fact, she habituated this cultural preference and capital in her daughter's unconscious mind, Alice. This can point to the 
fact that habitus is capable of maintaining itself over a long period of time. According to Bourdieu, habitus is "a durably installed generative principle of regulated improvisations" (Outline 78) that dictates how a person experiences the world, what they think and perform, and their norms, values, and practices. It can be understood as "the values and dispositions gained from our cultural history that generally stay with us across contexts [...] they are durable and transposable" (Webb et al. 36). The habitus is incorporated at the level of an unconscious set of bodily movements, dispositions, and styles. According to Webb et al., as subjects "move through and across different fields, they tend to incorporate into their habitus the values and imperatives of those fields. And this is most clearly demonstrated in the relationship between field and habitus functions to 'produce' [...] bodies and bodily dispositions" (37).

Therefore, individuals' dispositions are reflected in their actions and behavior unconsciously. Individuals' dispositions are "all invisible, but also marked in and through a person's bodily hexis and socio-cultural behavior" (Huang 48). Marriage dispositions can be observed in Alice's behavior, way of thinking, and actions. There are numerous examples throughout the novel that manifest the effect of these cultural dispositions and tastes on her that formed her habitus. Whenever Alice understands about a single man, she becomes emotional and first goes to the hairdresser's. "I have a hairdresser's appointment tomorrow [...] Do you think I should cut my hair?" (Pirzad 67). She also goes on a diet and tries to lose weight. "She went on a diet, for a few days or few weeks, depending upon how long the infatuation lasted. And, according to what she told us more than what our eyes could verify, she would lose weight" (Pirzad 67). Or when Alice finds out about Dr. Artamian's decision to marry another nurse, she becomes deeply upset. She believes that his chosen nurse is "the ugliest, dumbest, hickest girl God ever created" (Pirzad 34). Also, when Alice discovers that her sister's new neighbor is a single man, she asks her sister to arrange a party at Nina's home, Clarice's friend, and invite the Simonians to the party, as well. Therefore, she can meet him and marry him. "You could have told them to come to Nina's on Thursday night" (Pirzad 93).

Eventually, Alice meets a Dutchman called Joop at one of the parties at Nina's home, and they decide to marry each other. When Alice can become successful to achieve the cultural capital of marriage in the patriarchal society of Iran, she becomes transcendent, and her habitus changes. Before her marriage, Alice "had been flinging accusations left and right, night and day. And she had her opinions about the smallest details of everybody's business and would determine for them just 
exactly what they should do" (Pirzad 258-59). But after her marriage, changes in her behavior and habitus are obvious, especially when Clarice and her mother are talking about the Simonian's sudden departure. Alice tells her mother, "don't accuse people without cause. We don't know what happened. Anyway, it's none of our business" (Pirzad 258). This is because although habitus is durable and relatively continuous, it can incorporate changes within and across different contexts and conditions. Webb et al. state that "habitus is oriented towards the practical: dispositions, knowledges, and values are always potentially subject to modification rather than being passively consumed or reinscribed. This occurs when the narratives, values, and explanations of a habitus no longer make sense" (41). In other words, "a person's behavior and practices reflect his/her cultural history, and that history is always open to change and development" (Huang 48-9). The relationship between these two concepts is interrelation rather than individual existence. Bourdieu points out that "Systematicity is found in the opus operatum because it is in the modus operandi. It is found in all the properties- and property- with which individuals and groups surround themselves, houses, [...], and in the practices in which they manifest their distinction, games, entertainments, only because it is in the synthetic unity of the habitus, the unifying, generative principle of all practices" (Distinction 173).

\section{Conclusion}

The acquisition of the conclusion in this paper is based on the theoretical concepts of Bourdieu's theory of practice, as well as, the contextual analysis of the selected novels that provide objective evidence for a better understanding of masculine domination and Iranian women's submissiveness in the fields of vocation and marriage. Bourdieu believes that "involvement in a field shapes the habitus, which in turn shapes the perceptions and actions" leading to a reproduction of the rules of the field (Crossley 101). Social practices can be explained in terms of "the relationship between habitus and capital occurring within the specific logic of a given field" (Barnaby 17). For Bourdieu, it is the interaction of habitus, cultural capital, and field that generates the logic of practice.

The relation between habitus and field operates in two ways. On one side, it is a relation of conditioning: the field structures the habitus, which is the product of the embodiment of the immanent necessity of the field. On the other side, it is a relation of knowledge or cognitive structure: habitus contributes to constituting the field as a meaningful 
world, a world endowed with sense or with value, in which it is worth investing one's energy. (Reay 435)

Thus, Bourdieu's theory of practice can be summarized as "[(habitus) (capital) + field = practice" (Bourdieu, Distinction 101).

In her novel, Vafi demonstrates that men in the patriarchal society of Iran propagate different forms of cultural capital to limit women's domain activity to the domestic sphere and consider running the housekeeping matters and motherhood responsibilities as important forms of cultural capital for women in the field of vocation. These cultural norms are internalized in the female character of the novel and have turned into her habitus. Therefore, masculine domination and Iranian women's submissiveness continue to function because the "social logic of what is called vocation" produces "harmonious encounters between dispositions and positions in which the victims of symbolic domination can felicitously perform the subaltern or subordinate tasks that are assigned to the virtues of submission" (Bourdieu, Masculine 57). This can refer to the symbolic violence raised by Bourdieu because women accept their culturallycreated dispositions in the field of vocation and consider them as normal matters that are naturally existed in the order of the things.

In Pirzad's novel, the importance of cultural capital in the creation of women's dispositions and habitus that can lead to their submissiveness in the field of marriage is manifested through the female characters. Actually, the way that the female characters in these novels act in the field of marriage reflects the fact that they tend to adjust their practices to "what is realistically available and do not seek to go beyond those bounds" (Stewart 60). Through her three female characters, Pirzad reflects the fact that there are several valued forms of capital in Iranian women's marriage field. These forms of capital have penetrated deeply into the unconscious minds of all the inhabitants of Iran's patriarchal society as something normal and natural. Mrs. Nurollahi is encouraged to follow the capital of parallel-cousin marriage. Mrs. Nurollahi, who resists this prevailing capital of marriage and also her parents' will, ultimately marries a man with whom it is not clear whether she feels satisfied or not. This is generalized to the ignorance of the established patriarchal forms of cultural capital. Elmira Simonian cannot have any opinions about the choice of her future husband and cannot marry the person she loves. Her destiny in her marriage field is closely related to economic and social capital. Marriage as a form of cultural capital and necessity for single girls is reinforced in Alice by her mother. This capital dominates all her thoughts and performances. 
Therefore, the logic of masculine domination and feminine submissiveness, "which can be described as both spontaneous and extorted, cannot be understood until one takes account of the durable effects that the social order exerts on women (and men), that is to say, the dispositions spontaneously attuned to that order which it imposes on them" (Bourdieu, Masculine 38).

\section{Works Cited}

Barnaby, Mary. The Social Location of Widows. 1997. U of Plymouth, PhD Dissertation. Core.ac.uk/download/pdf/29817871.pdf.

Beckman, Karley, et al. "Conceptualizing Technology Practice in Education Using Bourdieu's Sociology." Learning, Media and Technology, vol. 43, no. 2, 2018, pp. 1-14. Taylor \& Francis Online, doi: 10.1080/17439884.2018.1462205.

Bourdieu, Pierre. Distinction: A Social Critique of the Judgement of Taste. Translated by Richard Nice, Harvard UP, 1987.

---. Masculine Domination. Translated by Richard Nice, Stanford UP, 2001.

---. Outline of a Theory of Practice. Translated by Richard Nice, Cambridge UP, 1977.

---. Pascalian Meditations. Translated by Richard Nice, Polity Press, 2000.

---. Sociology in Question. Translated by Richard Nice, Sage, 1993 [1980].

---. "The Family Spirit." Practical Reason, Polity Press, 1998.

---. The Field of Cultural Production: Essays on Art and Literature. Polity Press, 1993.

---. "The Forms of Capital." Handbook of Theory and Research for the Sociology of Education, edited by John Richardson, Greenwood, 1986, pp. 241-58.

---. The Logic of Practice. Translated by Richard Nice, Polity Press, 1992.

Bourdieu, Pierre, and Loïc J. D. Wacquant. An Invitation to Reflexive Sociology. $\mathrm{U}$ of Chicago $\mathrm{P}, 1992$.

Crossley, Nick. "The Phenomenological Habitus and Its Contribution." Theory and Society, vol. 30, no. 1, 2001, pp. 81-120. Springer Link, doi: 10.1023/A:1011070710987.

Everett, Jeffery. "Organizational Research and the Praxeology of Pierre Bourdieu." Organizational Research Methods, vol. 5, no. 1, 2002, pp. 5680. Sage pub, doi: 10.1177/1094428102051005.

Franklin, Vincent P. "Cultural Capital and African American Education." Journal of African American History, vol. 87, no. 2, 2002, pp. 175-181. U of Chicago P Journals, doi: 10.1086/JAAHv87n2p175.

Grenfell, Michael. "Applying Bourdieu's Field Theory: The Case of Social Capital and Education." Education, Knowledge, and Economy, vol. 3, no. 1, 2009, pp. 17-34. Taylor \& Francis Online, doi: 10.1080/17496890902786812.

---. Pierre Bourdieu: Key Concepts. Acumen Publishing Limited, 2008.

Huang, Xiaowei. "Understanding Bourdieu- Cultural Capital and Habitus." Review of European Studies, vol. 11, no. 3, 2019, pp. 45-49. Canadian Center of Science and Education, doi: 10.5539/res.v11n3p45. 
Krais, Beat, and Jennifer Marston William. "The Gender Relationship in Bourdieu's Sociology." $U$ of Wisconsin P, vol. 29, no. 3, 2015, pp. 53-67. JSTOR, doi: 10.2307/3685561.

Lagaert, Susan. Gender and Cultural Tastes: An Intrapersonal, Interpersonal and Contextual Approach. 2017-18. Ghent U, PhD Dissertation. UGent Biblio, biblio.ugent.be/publication/8565906/file/8565908.pdf.

Lovell, Terry. "Thinking Feminism with and against Bourdieu." The Sociological Review, vol. 49, no. 1, 2001, pp. 27-48. SAGE Journals, doi: $10.1177 / 14647000022229047$.

McNay, Lois. "Gender, Habitus and the Field: Pierre Bourdieu and the Limits of Reflexivity." Theory, Culture \& Society, vol. 16, no. 1, 1999, pp. 95-117. Sage Journals, doi: 10.1177/026327699016001007.

Pirzad, Zoya. Things We Left Unsaid. Translated by Franklin Lewis, Oneworld Publications, 2012.

Reay, Diane. "It's All Becoming a Habitus: Beyond the Habitual Use of Habitus in Educational Research." British Journal of Sociology Education, vol. 25, no. 4, 2004, pp. 431-44. Taylor \& Francis Ltd, doi: $10.1080 / 0142569042000236934$.

Sayce, Susan. "Gender Change? Looked into Industrial Relations and Bourdieu." Employee Relations, vol. 25, no. 5, 2006, pp. 468-82. Emerald Insight, doi: 10.1108/01425450610683663.

Sayyadi Nejad, Rouhollah, and Zahra Mortezae. "Comparative Study of Women Portrait in Fariba Vafi's and Sahar Khalife's Writings Studied Cases: My Bird and I'm Not Your Slave Anymore." Scientific Research Quarterly of Woman and Culture, vol. 9, no. 34, 2018, pp. 63-80. Women and Culture Journal, https:// jwc.iauahvaz.ac.ir/article_538847_en.html.

Shahbazi, Mahshad, et al. "Evolution of Self-Awareness in the Works Iranian Women Novelists, Based on the Transformation Theory of Ellen Showalter." Women in Culture and Art, vol. 10, no. 2, 2018, pp. 285-309. Doi: 10.22059/JWICA.2018.236858.908.

Silva, Elizabeth B. "Gender, Home and Family in Cultural Capital Theory." The British Journal of Sociology, vol. 56, no. 1, 2005, pp. 83-103. Wiley Online Library, doi: 10.1111/j.1468-4446.2005.00048.x.

Skeggs, Beverley. "Context and Background: Pierre Bourdieu's Analysis of Class, Gender and Sexuality." Feminism after Bourdieu, edited by Lisa Adkins and Beverley Skeggs, Blackwell, 2004, pp. 19-33.

Stewart, Simon. "Why Do We Like What We Like?" A Sociology of Culture, Taste and Value: Introduction, Palgrave Macmillan UK, 2013, pp. 56-74.

Swartz, David. Culture and Power: The Sociology of Pierre Bourdieu. U of Chicago $P, 1997$.

Vafi, Fariba. My Bird. Translated by Mahnaz Kousha and Nasrin Jewell, Syracuse UP, 2009.

Webb, Jen, et al. Understanding Bourdieu. Edited by Rachel Fensham and Terry Threadgold, Allen \& Unwin, 2002. 
Winkle-Wagner, Rachelle. "Cultural Capital: The Promises and Pitfalls in Educational Research:AEHE" John Willey \& Sons, vol. 36, no. 1, 2010, pp. 1-21.

\section{KULTURNI KAPITAL I POTČINJENOST IRANSKE ŽENE: TEORIJA PRAKSE PJERA BURDJEA}

U ovom radu istraživači ukazuju na to kako kultura kao oblik kapitala može imati veliki uticaj na rodno zasnovanu podjelu rada u polju struke, kao i na podređeni položaj žene u braku u patrijarhalnom iranskom društvu u svjetlu teorije prakse Pjera Burdjea. Analiza je od značaja jer osvjetljava status iranske žene u oblasti struke i u bračnoj zajednici i demonstrira načine na koje muškarci u patrijahralnom društvu Irana iskorišćavaju kulturu kao kapital da bi ostali u vlasti moći i da bi je reprodukovali, čineći da podređena uloga žena u ovim poljima izgleda prirodna čak $i$ sa tačke gledišta Burdjeove teorije prakse. Različite forme kulturnog kapitala autori dovode u vezu sa nastavkom masculine dominacije i ženskog potčinjavanja na poslu i u braku identifikujući i ispitujući u izabranim romanima status ženskih likova, oblasti njihovog profesionalnog angažovanja, kao i brak, kao unaprijed određene patrijarhalnom kulturom i njenim otelovljenjem u nesvjesnom ženskom umu. Konačno, posredstvom primjera istraživači ukazuju na negativne i razarajuće efekate koje na žensku egzistenciju mogu imati različite forme kulturnog kapitala uspostavljene i prihvaćene na taj način.

Autori u prvi plan ističu kulturni kapital kao važan faktor za razmatranje brojnih rodnih pitanja uključujući i pitanje profesionalnog angažovanja i braka. U radu je kao osnov uzeta teorija prakse Pjera Burdjea s namjerom da se interpretacija usredsredi na značajnu ulogu kulture kao oblika kapitala u određenju, opterećenju i postavljanju ograničenja ženi na polju struke i u braku. Rad omogućava bolje razumijevanje muško-ženskih odnosa u iranskom društvu i pruža objašnjenje po kojem je podređenost žene u njemu rezultat kulturnog konstrukta patrijarhata. Takođe, rad nudi razloge zbog kojih iranska žena nije u mogućnosti da promjeni ili poboljša sopstveni položaj.

Keywords: Pjer Burdje, kulturni kapital, polje, habitus, simboličko nasilje, struka, brak, Moja ptica (My Bird), Sve što nijesmo rekli (Things We Left Unsaid) 